\title{
The Movement for Women's Rights during the Indian National Movement
}

\author{
Alisha Dhingra \\ (Department of Political Science, University of Delhi, India)
}

\begin{abstract}
The Nationalist Movement not only brought women out of their homes, but also provided an opportunity for women to join hands together and to fight for their rights Many women organizations were formed in different parts of the country and three women organizations were 'all-India' in character with branches in different regions. In the early years of their formation, these organization campaigned for women's right to education and political participation (right to vote and contest elections). By the 1930s they broadened their agenda to ask for reform in personal laws which ultimately led the government to appoint a committee in 1941headed by B.N. Rau to draft Hindu Code Bill.
\end{abstract}

Keywords - Equality, Movement, Nationalist, Organizations, Rights

\section{INTRODUCTION}

Partha Chatterjee has argued that the national movement moved out the issue of women's emancipation from the political domain onto the cultural/ spiritual and made it non- negotiable with the colonial state. Roy points out that the nationalist silence on the women's question was punctured by women's organized struggle for equal political rights vis-à-vis voting and sitting in legislatures and for reforms in personal laws.[1]

Vir Bharat and Indrani Chatterjee have pointed out that a discourse of equality began to develop in the late 1910 s and 1920s, amongst women who had been active in nationalist or women's rights campaigns. These women not only linked women's rights with nationalism but also used nationalist arguments to defend demands for women's rights to equality with men.[2]

Radha Kumar points out that by the 1920s, two different rationales for women's rights were being expressed. The former was based on complementarity between men and women and emphasized on women's socially useful role as mothers, while the latter believed that women have same needs, capacities and desires as men and thus deserve the same rights. [3]

The Indian women's movement hesitated to use the word 'feminist', despite recognizing that its priorities were not always the same as men. Kamaladevi Chattopadhyaya has pointed that Indian women sought political rights to perform their civil duties, and not to compete with men. Women saw their own advancement and India's freedom as being closely knit together: 'women's rights seemed dependent on freedom from colonialism. They saw themselves as working for women's rights even as they demonstrated, marched or supported revolutionary activities.[4]

Women saw both colonial structures and traditional hierarchical structures as a cause of gender inequality. While women were conscious of their dependence on the British government for acquiring positions on various legislative councils and committees, they were also conscious of the fact it was against the same government that they were fighting for India's political independence. The contradictory relations with the British government led to strengthening of women's alignment with the nationalist movement and promoted a view of women as political comrades of men. Liddle and Joshi point out that women leaders were conscious of the fact that an overemphasis on male supremacy as cause of their subordination would have served a justification for the British to continue their rule in India.[5]

It has been argued by some scholars that women's close and necessary relationship with the nationalist movement subsumed their own problems and demands, and limited their political perspectives. Jayawardena argues that even when women's issues were discussed, they covered limited reforms such as the right to vote, education and property, and equality within the legal process. These reforms had little effect on the daily life of the masses of women, neither they did address the basic question of women's subordination within the family and in society.[6]

The Mahila Rasgtriya Sangha, formed in 1928, was the first formal organization to mobilize women for political work. MRS leaders argued that the nation could not be free until women's lives improved and until the nation becomes free women's condition could not improve. The first step to swaraj was defined as the education of women to their double oppression as colonial subjects and inferior sex.[7] 
Organized activism by women for voting and representation unfolded in the context of the reforms in 1917 promising the gradual evolution of self-governing institutions. It gained momentum with subsequent reform declarations and all but withered away in the 1940s. The decline in 1940s was a manifestation of the unyielding primacy that the issue of political independence had assumed. [8]

\section{RIGHT TO EDUCATION}

Annie Besant asserted that in ancient times Hindu women were educated and moved freely in society. While campaigning for women's education, Besant rejected Western education which she believed would "unsex" women. She believed that Indians should look to their own ideal of womanhood- the Goddess Durga. [9] In one of her speeches supporting women's education, she said 'the national movement for girl's education must be on national lines; it must accept the general Hindu conceptions of women's place in the national life...India needs nobly trained wives and mothers, wise and tender rulers of the household, educated teachers of the young, helpful counselors of their husbands, skilled nurses of the sick, rather than girl graduates.' [10]

In 1926, the All India Women's Conference for Educational Reform was formed, its charter stated that they wanted an education that would fit Indian women to best perform their roles in the home, but simultaneously stated the need for vocational training for poor women. [11]

The majority of women at All India Women's Conference agreed that the educational system should concentrate on producing educated wives and mothers but they also wanted women doctors, professors, and lawyers. But regardless of whether the curriculum should stress natural science and home science, there was general agreement that education should complement gender roles.[12]

\section{RIGHT TO POLITICAL PARTICIPATION}

It is interesting to note the presence of women in 1889 Congress session (just four years after the formation of Congress) The report of the 1889 Congress mentions that 'no less than ten lady delegates graced the assembly, one elected by men at a public meeting, the others by various ladies associations, the Women's Christian Temperance Union, the Bengal Ladies' Association, and the Mahila Arya Samaj.' It was on the initiative by Ramambai that women delegates participated in this meeting. Charles Bradlaugh suggested to her that women delegates should join the Congress from this time on so that their concerns are taken up when Congress forms independent India's Parliament. The report did not mention the fact that though women delegates were allowed to sit in the meeting, but they were neither allowed to speak nor vote for resolutions. It was during 1890 session that one woman was allowed to speak or rather to present a vote of thanks to the President. In her speech, she thanked him for giving her the chance to speak, saying that this 'raised the status of our Indian women'.[13]

On December 15, 1917, Sarojini Naidu led an all-India delegation of prominent women to meet with Montagu and Chelmsford. They asked for the franchise on same terms as men. The following year, Naidu spoke on behalf of suffrage for women at the special session of Congress held in Bombay. She said,

"Never, never, for we realize that men and women have their separate goals, separate destinies and that just as man can never fulfill the responsibility or the destiny of a woman, a woman cannot fulfill the responsibility of man...We ask for the vote, not that we might interfere with you in your official functions, your civic duties, your public place and power, but rather that we might lay the foundation of national character in the souls of children that we hold on our laps, and instill into them the ideals of national life." [14]

5000 delegates attended this special session and the resolution was passed by 75 percent majority.[15] During the thirty-third session of the INC in December of 1918, Sarladevi Chaudhrani presented the resolution supporting the vote for women. Sarladevi asserted that women had as much right to chart their own destinies as men for this was the age of human rights, justice, freedom and self-determination. She said that the world has outgrown certain ideas, particularly the "fanciful division of intellect and emotion being the respective spheres of men and women." She contended that the "sphere of women" included comradeship with men in the rough and tumble of life and to being the fellow-workers of men in politics and other spheres."'[16]

In his first article on women in Young India, Gandhi stated that though he wanted women to take their proper place by the side of men but he would not suppport a "votes for women" campaign. [17]He advised women to liberate themselves and their menfolk "from the death grip of the existing government which is the greatest of all social evils with which society is cursed." Gandhi responded that the problem was not with law or religion but with man's lust. He believed that for real change to come, both men and women have to view their relationships differently. The solution, for Gandhi, laid in observing celibacy and not legal change.[18] An All Parties Conference was held in 1927, in which the first serious attempt to draw Constitution for India was made. Known as Nehru Report(because it was drafted by a group headed by Motilal Nehru, it was finalized at All-Parties Conference in 1928. It did not demand total Independence and asked for Dominion Status, but it raised the demand for adult suffrage for both men and women.[19] 
Kumar (1993) points out that though on one hand nationalism had a beneficial influence on feminism by drawing it out of its upper class enclave, on the other hand nationalism also created rift among feminists. Begum Shah Nawaz and Kamala Subbaryon attended First Round Table Conference(From November 1930 to January 1931) and raised the demand for women's reservation in legislatures arguing that women would reach parity with men only through initial reservation. Nationalist women vehemently oppsosed this argument and the Rashtriya Stree Saba and Desh Devika Sangh held demonstrations against the participation of Begum Shah Nawaz and Kamala Subbaryon in the Conference.

During the Second Round Table Conference, nationalist feminists presented a memorandum to the Conference which rejected all suggestions of concessions to women, whether reservation, nomination or cooption, and declaring that, 'to seek any form of preferential treatment would be to violate the integrity of the universal decision of Indian women for absolute equality of political status'.[20]

It is important to note that while the removal of sex discrimination formed the basis of women's demand for voting rights, women's organizations which took up the issue with the colonial government framed it within the larger agenda of 'universal franchise'. 'Fair field and no favours' was the preferred slogan of women activists. The prioritization of 'universal franchise', rather than an emphasis on women's suffrage, placed women's demands in accordance with the nationalist demand for 'national' citizenship and selfdetermination.[21] The provision of 'universal adult franchise' in the charter of rights adopted by the Indian National congress, in its Karachi Convention in 1931 can be seen as the public manifestation of this 'harmony', apparently achieved without the bitter 'sex war' suffrage had provoked in the west. Roy argues that this consensus, however, was a veneer which served to cover up the fundamental and contentious issues which the voting rights for women raised. The contours of debate obscured in the consensus reveal a complex interlocking of ideological formulations- colonialist, nationalist, masculinist and feminist- over the issue of women's proper place and the extent /nature of rights which suited it.[22] A careful distancing from the adoption of critical stance towards 'their' men, while appealing to the colonizer was a persistent characteristic of women's campaigns. Yet women's activism also took shape in connection with suffragist feminists in other countries, in particular Irish and British suffragists some of whom were also campaigning in India. It is interesting to see how this association wavered between moments of solidarity in a universal sisterhood and moments when sisterhood was ruptured by the national anxieties of 'Indian feminists'[23]

Roy argues that the debates in the various legislative councils and women's campaigns to garner the support of the legislative councilors reasserted the collapsing of womanhood and motherhood, the home with the nation, and the distancing of women's specific social activities from the political activities of men. Those in favour of the extension of vote to women argued that women's maternal role of exercising guidance over their children enabled them to determine the laws guiding the entire population. Those against the grant to women argued that the participation of women in public life would cripple family life and distract responsible mothers from domestic duties. They warned of reversal of traditional gender roles. Their main fear was that Indian women may imitate Western women whose shameless behavior they dejected.[24]

The India Act of 1935 fixed the ratio of voters at 1:5. There were very few women who regarded this as a significant victory. To many women it appeared as a betrayal from all their allies and so-called well-wishers. It became clear that the British officials and administrators were interested in managing the women's question without challenging the status quo. Though British women tried to be helpful but they were convinced of the efficacy of the British rule. "Indian males who led Congress agreed to compromises without consulting women's organizations." [25]

\section{EMERGENCE OF WOMEN'S ORGANIZATIONS}

Three major women's organizations at the national level emerged during the period (1917-1927). These were Women's Indian Association (WIA), All India Women's Conference (AIWC) and National Council for women in India (NCWI). The issues that were most prominent in the campaigns of these organizations were related to marriage, divorce and inheritance and towards expanding educational and economic opportunities to women. [26]

The Women's Indian Association was the first women's organization to take up women worker's demands. The demand for maternity leave was first put forward in the 1921 Jamshedpur strike. It also found mention in the charter of All India Trade Union Congress in the year the organization was formed. The Bombay Maternity Benefit Act was passed in 1929 followed by similar legislation in other provinces. [27]

The All India Women's Conference was the most important women's organization in the preindependence period. Initially, the majority of the members of the Conference were from upper class and Hindu families. Forbes points out that the acceptance of "golden age" theory by the members of the Conference limited their potential to attract women from other communities and classes. It also inhibited a radical feminist critique of their society. The leaders were cognizant of the fact that their work was taking them in two directions: one that would benefit women specifically and one aimed at helping the entire nation. Their work on behalf of women was increasingly concentrated on legal disabilities while the concern with the welfare of the nation 
drove them toward Gandhi's program of reconstruction and social action. Their concern in women' status in law pushed them towards collaboration with British officials and members of the legislature while the Gandhian emphasis on village uplift and untouchables involved work at the grass-roots level as well as a totally different interpretation of dynamics of social change.[28]

Sadhna Arya points out that the efforts of these organizations were limited by various factors. Firstly, there was a clear dichotomy between the perception of male leadership and that of women's leaders. For example, Gandhi did not agree that agitating for legal rights was the right way to gain justice. Moreover, many Congress leaders felt that this was not a priority issues and were unwilling to work with British to secure legislations concerning women's rights. This required that legislative reforms need to be stalled till the time the country gains independence. Secondly, there was significant opposition to reforms from conservative sections of society. [29]

Forbes argues that both the success and failures of women's organizations can be attributed to social feminism which served as the ideological basis for their demands. Although, many members of these organizations decried the term 'feminism', since they equated with man-hating and suffragette violence, they nevertheless sought greater autonomy for women. They petitioned for education, the vote and amelioration of social evils to enable women to fulfill their social duties to the family and nation. It needs to be noted that a few women within these organizations questioned the double standard and demanded complete autonomy for women. But their views remained subordinated to those of majority. Forbes point out that the reason these organizations refrained from adopting a radical ideology was that these organizations matured with male support and flourished in partnership with male-dominated nationalist parties. It allowed them to refrain from making a difficult choice between nationalism and feminism. The development of a social feminist ideology made possible the peaceful coexistence of feminism and nationalism in a new construct what Margot Badran has termed as "feminist nationalism". What one needs to remember is the fact that their attempts to change social reality for women were played out in an environment that could be especially cruel to women who did not conform. [30]

\section{CLAIMING EQUALITY}

By the 1930s, there was a considerable shift in the nature of demands being made by the leaders of the women's movement. There was a shift from earlier discourse on women's upliftment to a discourse on gender equality. This shift was probably the result of the belief on the part of leaders of the women's movement that their concerns would be favourably received in the changed political atmosphere. As Jane M. Everett has pointed out, "...women leaders were appealing to values influential among the Indian political elite of 1930s."[31] The discourse of freedom from imperialist rule and the need to broaden the mass base of the national movement entailed that the issues of denial of freedom and rights of deprived sections like the lower castes and women as emanating from the hierarchical ordering of Indian, and more specifically Hindu society, were also addressed. The approach of the nationalist leadership to women's issues was clearly reformist as a radical change in the position of women in Indian society required changes in the family and marriage system as sanctioned by religious and social norms. Arya, points out that while the liberal feminist demands of improving women's position in education, employment, politics and in property rights were acceptable, a radical reordering of social relationships so as to extend the principle of gender equality did not fit well with the reformist perspective of the nationalist elite. Thus, there was a contradiction between the equal rights perspective of women leaders and paternalistic attitude of national leaders.[32]

When it became clear that the Bengal Congress was not interested in women's issues, women's leaders called for a meeting to form a separate women's Congress. Bengal Women's Conference was held in May 1931 where Sarladevi Chaudhrani made a provocative speech with a clear feminist agenda. Though she acknowledged men's role in bringing women in the freedom movement, but raised doubts whether they were really concerned about improving women's status. She asserted that women were rewarded with flowery speeches but not appoint ted to sub-committees and councils. She said that Congress assigned to women only the position of law-breakers and not law-makers. She asserted the time has come to speak publicly about the status of women and to join the world-wide women' movement. She asked why the Congress never conceived of an anti-brothel campaign. She gave a call for legal, economic, social and educational equality. The audience which Sarladevi addressed was not as radical as her and in their final session they reiterated the usual demands, rejected resolutions favouring birth control and equal treatment for women and decided not to form separate women's Congress. [33]

In 1934, the AIWC after getting disappointed with both the Sarda Act and the proposed India Act, asked the government to appoint an all commission to consider the legal disabilities of women. The issues they brought to light were inheritance, marriage and guardianship of children. Their ultimate goal was to bring forth a new law. Renuka Ray, the legal secretary of the AIWC, authored a pamphlet titled: Legal Disabilities of Indian Women: A Plea for a Commission of Enquiry. She argued in favour of new laws for all women, regardless of 
community. She wrote that the legal position of Indian women was one of the most inequitable in the world today. Ray asked for new personal and family law that would make women independent and fully equipped to participate in public life. Assembly Bills introduced in 1930s indicate a piecemeal approach to improving women's status. Some of the measures concerning women's rights introduced between 1937 and 1938 were the Hindu Woman Right to Property Bill, an amendment to the Child Marriage Restraint Act, a bill to allow intercaste marriage, the Hindu Woman's right to Divorce Act, the Muslim Personal Law Bill, the Prevention of Polygamy Bill and the Muslim Women's Right to Divorce Bill. In the provincial legislatures anti-dowry bills, marriage laws and bills allowing women to inherit were introduced.[34]

During the discussion on these bills, it became clear that male reformers and the women's organizations had different concepts of women's legal needs. G.V. Deshmukh introduced the Hindu Woman's Right to Property Bill in which he proposed an equal share for wives and daughters with male heirs if the head of the family died intestate. On the other hand, members of the Bhagini Samaj, a Bombay women's organization, wrote a memo to the government suggesting a new law of succession "where the female heirs will come as heirs according to modern notions.'[35]

Women activists who advocated equal rights decided to support every law that seemed progressive. Gandhi disagreed with these tactics, he urged women activists to spend their time in the villages learning about local customs. This would enable them to understand that legal changes were irrelevant for most rural women. The INC also proved to be an equally difficult ally as only few Congress members agreed that women's legal rights deserved the highest priority. AIWC report asserted, "It is our birthright to demand equitable adjustment of Hindu Law regarding women's rights according to the requirements of present conditions of our society." Though Jawaharlal Nehru supported women's participation in public life but he privileged agrarian reform over family law reform and was against collaborating with the British to gain women's rights legislation. [36]

The bills introduced were defeated one by one. "The debates shocked the women leaders who were unaware of the opposition's intractability. Begum Hamid Ali deplored the "utterly unsympathetic attitude of the men in the assembly and concluded they were afraid they might lose half of their land, power and money." She agreed that legal reform is incapable in itself to solve all women's problems, but nevertheless, it will provide financial security to some women who could their own lives and care of their children. It is pertinent to note that women increasingly couched their pleas in terms of human rights and spoke less often about the special contribution of politics. Begum Hamid Ali said, "Women are asking nothing more than just and humane treatment and to be liberated from their disabilities".[37]

The government agreed to appoint a committee of eminent lawyers to study law and make recommendations, but it was delayed till 1941 due to the war and political disturbances. In January 1941, Sir B.N. Rau was appointed as the chair of the committee. The request to add a woman to the committee was ignored. It was for the first that all women's organizations worked hard to support a measure. They worked cooperatively to gather information for the Rau Committee.[38]

By 1941 the Indian National Congress was boycotting the legislatures which presented a dilemma for women who were both nationalists and activists: should they cooperate with Rau Committee to secure rights for women or join the Congress boycott? Gandhi dismissed the Rau Committee as a government ploy to divert attention from real issues, but he refrained from asking women to boycott the Committee. He instead reached a compromise solution: women who wanted to work with Rau Committee could do so in their individual capacity but not as spokepersons for any group. Mridula Sarabhai though admitting that this proposed reform was the "equivalent to what a Temple Entry Bill would mean to Harijan workers", but urged women to stand solidly behind the Non-cooperation Movement. Other Congress female stalwart like Sarojini Naidu, Vijaylakshmi Pandit and Amrit Kaur continued to call for legal reform. Congress women in the Central Legislative Assembly, Mrs. Renuka Ray and Mrs. Radhabhai Subbarayan spoke in favour of Rau's Committee work.[39]

\section{SOCIO-ECONOMIC RIGHTS}

The Indian National Congress at its Karachi session in 1931, adopted a resolution on fundamental rights, which was seen as manifestation of commitment of Congress leadership to equal political and civil rights for women in Independent India. Nehru played a significant role in emphasizing the economic content of women's rights. Nehru demurred from one sided and limited view of education and pleaded that women should be trained in every department of human activity so that they can play an productive role in various professions and other spheres of social life. While addressing women in 1934, Nehru asserted that without economic freedom, other aspects of equality will prove superficial. He said, "Freedom depends on economic conditions even more than political and if woman is not economically free and self-earning she will have to depend on her husband or someone else and dependents are never free". His views on marriage, women's education, their rights in parent's property and prostitution were in variance with the views of other social reformers and nationalist leaders including Gandhi. In Nehru's approach economic well being of women was priortised over moral emancipation and his emphasis on women's equality and independence was unequivocal. He was 
conscious of the fact that women had to engage in a two-fold struggle: against imperialism and against men. He warned that Fundamental Rights resolution should not be seen as ultimate victory for women's equality with men since there were many who voted for the resolution with considerable mental reservations. He said, "Politically they have already extorted admiration of the men of India. But their task in the social field is far harder; as soon as they try to rid themselves of their heavy social burdens, they come up against social customs and man's prejudices and interests." [40]

A National Planning Committee was instituted with Jawaharlal Nehru as its Chairman in 1937. 29 subcommittees were set up to report on different facets of planned development, one among these was the SubCommittee on Women's Role in Planned Economy. Some of the rights that found mention by the subcommittee were equal voting rights as individual, the rights to hold public office or employment, the right to work as implied in the demand for equal access to public services and equal wages for equal work without endangering employment opportunities for women, the right to choose one's nationality, equal rights to health, leisure and recreation. The report is percolated by the idea that housewives were also working women. The concept of fixed hours of work, adequate relief from duties in the kitchen, cooperative efforts to relieve/sharing household duties etc., sought to expand the scope and meaning of women's work.[41]

The report enshrined economic independence not only in terms of equal access to employment, but more importantly in making women co-sharers in the collective income and resources of the family. The report also laid emphasis on the economic value of women's work at home and asked for recognition for their contribution in family production. The report also made recommendations for improvement of the condition of working women by asking for equal wages, equal work opportunities, child care services etc.[42]

\section{CONCLUSION}

The Nationalist Movement not only brought women out of their homes, but also provided an opportunity for women to join hands together and to fight for their rights Many women organizations were formed in different parts of the country and three women organizations were 'all-India' in character with branches in different regions. In the early years of their formation, these organization campaigned for women's right to education and political participation (right to vote and contest elections). By the 1930s they broadened their agenda to ask for reform in personal laws which ultimately led the government to appoint a committee in 1941 headed by B.N. Rau to draft Hindu Code Bill.

Sadhna Arya takes note of two important facts about campaign for women's rights during this period. Firstly, women's groups focused on problems faced by all women cutting across all communities, Secondly, there was a clear-cut concern on getting financial security in the form of equal share in property rights. Arya points out that law was not seen as a revolutionary measure that would drastically change their oppressive conditions but was definitely seen as a measure empowering them to secure greater equality and financial security.[43]

The female students in nationalist era were inspired by an ideal of male-female equality. The feminist ideas permeated only elite circles and when these leaders began organizing women's processions, they became deeply aware of the strength of conservative attitudes. Elite women leaders wanted to mobilize their less sophisticated sisters for political action and they knew this would be impossible without the permission of their husbands and fathers. Therefore, out of expediency, nationalist issues were concentrated and feminist issues were left out of the speeches by women leaders. [44]

\section{REFERENCES}

[1] Anupama Roy, Women's Movement in N.G. Jayal and P.B. Mehta (Ed.) Oxford Companion to Indian Politics (New Delhi, Oxford, 2010). 411.

Radha Kumar, The History of Doing (New Delhi, Zubaan, 1993). 65-66.

Radha Kumar, The History of Doing (New Delhi, Zubaan, 1993). 66.

Suruchi Thapar Bjorkert, Women in the Indian National Movement (New Delhi, Sage, 2006).45.

Suruchi Thapar Bjorkert, Women in the Indian National Movement (New Delhi, Sage, 2006).45-46.

Suruchi Thapar Bjorkert, Women in the Indian National Movement (New Delhi, Sage, 2006). 46.

Geraldine Forbes, Women in Modern India (New York, Cambridge University Press, 1996). 135-136.

Anupama Roy, Women's Movement in N.G. Jayal and P.B. Mehta (Ed.) Oxford Companion to Indian Politics (New Delhi, Oxford, 2010). 411.

Geraldine Forbes, Women in Modern India (New York, Cambridge University Press, 1996). 45-46.

Radha Kumar, The History of Doing (New Delhi, Zubaan, 1993). 66.

Radha Kumar, The History of Doing (New Delhi, Zubaan, 1993). 69.

Geraldine Forbes, Women in Modern India (New York, Cambridge University Press, 1996).81.

Radha Kumar, The History of Doing (New Delhi, Zubaan, 1993). 34.

Geraldine Forbes, Women in Modern India (New York, Cambridge University Press, 1996).93-94

Geraldine Forbes, Women in Modern India (New York, Cambridge University Press, 1996).94.

Geraldine Forbes, Women in Modern India (New York, Cambridge University Press, 1996).94.

Geraldine Forbes, Women in Modern India (New York, Cambridge University Press, 1996).100.

Geraldine Forbes, Women in Modern India (New York, Cambridge University Press, 1996).128.

[18] Geraldine Forbes, Women in Modern India (New York, Cambridge U
[19] Radha Kumar, The History of Doing (New Delhi, Zubaan, 1993). 74. 
[20] Radha Kumar, The History of Doing (New Delhi, Zubaan, 1993). 81.

[21] Anupama Roy, Women's Movement in N.G. Jayal and P.B. Mehta (Ed.) Oxford Companion to Indian Politics (New Delhi, Oxford, 2010). 411-412.

[22] Anupama Roy, gendered citizenship (New Delhi, Orient Longman, 2005). 125.

[23] Anupama Roy, Women's Movement in N.G. Jayal and P.B. Mehta (Ed.) Oxford Companion to Indian Politics (New Delhi, Oxford, 2010). 412.

[24] Anupama Roy, gendered citizenship (New Delhi, Orient Longman, 2005). 102

[25] Geraldine Forbes, Women in Modern India (New York, Cambridge University Press, 1996).112.

[26] Sadhna Arya, Women, Gender Equality and the State (New Delhi, Deep and Deep, 2000). 44-45.

[27] Radha Kumar, The History of Doing (New Delhi, Zubaan, 1993). 67.

[28] Geraldine Forbes, Women in Modern India (New York, Cambridge University Press, 1996).81.

[29] Sadhna Arya, Women, Gender Equality and the State (New Delhi, Deep and Deep, 2000). 45.

[30] Geraldine Forbes, Women in Modern India (New York, Cambridge University Press, 1996).90-91.

[31] Sadhna Arya, Women, Gender Equality and the State (New Delhi, Deep and Deep, 2000). 55.

[32] Sadhna Arya, Women, Gender Equality and the State (New Delhi, Deep and Deep, 2000). 55-56.

[33] Geraldine Forbes, Women in Modern India (New York, Cambridge University Press, 1996).143.

[34] Geraldine Forbes, Women in Modern India (New York, Cambridge University Press, 1996).113.

[35] Geraldine Forbes, Women in Modern India (New York, Cambridge University Press, 1996).114.

[36] Geraldine Forbes, Women in Modern India (New York, Cambridge University Press, 1996).115.

[37] Geraldine Forbes, Women in Modern India (New York, Cambridge University Press, 1996).116.

[38] Geraldine Forbes, Women in Modern India (New York, Cambridge University Press, 1996).116.

[39] Geraldine Forbes, Women in Modern India (New York, Cambridge University Press, 1996).117.

[40] Sadhna Arya, Women, Gender Equality and the State (New Delhi, Deep and Deep, 2000). 47.

[41] Anupama Roy, gendered citizenship (New Delhi, Orient Longman, 2005). 213-214.

[42] Sadhna Arya, Women, Gender Equality and the State (New Delhi, Deep and Deep, 2000). 48.

[43] Sadhna Arya, Women, Gender Equality and the State (New Delhi, Deep and Deep, 2000). 46.

[44] Geraldine Forbes, Women in Modern India (New York, Cambridge University Press, 1996).149. 